\title{
PROFESSIONAL FORMATION OF FUTURE SOCIAL SPECIALISTS: PRACTICAL ASPECT
}

\author{
Yana Raievska ${ }^{1}$ \\ Zhanna Melnyk ${ }^{2}$
}

DOI: https://doi.org/10.30525/978-9934-588-38-9-46

Abstract. The article deals with the aspects of professional development of social work specialists; professional roles and functions and content of professional activity are stated; the leading principles of organizational and methodological support of the process of training of social specialists are defined. Implementation of the leading criteria and indicators is characterized by a number of contradictions that characterize the interaction of various aspects of training social specialists, which have inconsistency or inconsistency under the influence of social problems, socially dangerous phenomena, requirements of social work and society's requirements to a specialist in the social sphere.

Professional activity of an individual in a social sphere depends on the specificity and type of work (professional practice or academic discipline) that has its own theories of social work.

The content structure of vocational education which includes social, psychological, pedagogical, and methodical components is analyzed.

The structure of multidisciplinary integration in the process of training specialists in the social sphere, which includes gradual acquisition of the necessary knowledge by future specialists that influence of the readiness of future social workers is developed. Such integration requires a complex solution of tasks, including the social worker activity in providing clients

\footnotetext{
${ }^{1}$ Ph.D. in Psychology,

Assistant Professor of the Department of Social Pedagogy and Social Work, Ivan Ohienko National University in Kamianets-Podilskyi, Ukraine

Doctoral Student,

G.S. Kostiuk Institute of Psychology NAPS of Ukraine, Ukraine

ORCID: https://orcid.org/0000-0003-3802-2304

Researcher ID C-8527-2019

${ }^{2}$ Ph.D. in Psychology,

Assistant Professor of the Department of Social Pedagogy and Social Work, Ivan Ohienko National University in Kamianets-Podilskyi, Ukraine

ORCID: https://orcid.org/0000-0003-3348-0939
}

(C) Yana Raievska, Zhanna Melnyk 
with socio-economic services. The interdisciplinary approach will provide an opportunity to study the research object using the scientific accumulation of already acquired knowledge. The study of individual disciplines should be accompanied by the establishment of techniques and approaches to the interdisciplinary educational material presentation, which forms interdisciplinary thinking, that will contribute to the successful professional development of social field specialists.

The role of practice in the system of training specialists in the social sphere is defined. We consider the practical training system as a structural component of an integrated university vocational training system. After all, practical training includes not only the traditional elements adopted in many educational institutions, such as introductory, educational and occupational, practice within the specialization, but also significant changes and additions to theoretical courses: fulfillment of laboratory tasks, practical assignments and term papers related to the aspects of practice conceptually, substantively and organizationally; specifically arranged training sessions and workshops; exchange of experience, research-practical and methodical conferences; volunteer activity in occupational associations and public organizations.

\section{Introduction}

The specificity of modern social work requires a high professional level. The professionalism of a particular employee is the result of his or her self-realization throughout a long-term process of professional formation, characterized by individual identity and uniqueness of the conditions.

Professional formation of social work specialists is a holistic and continuous process of development of practical, educational and research activities of the individual in the social sphere, focused on the formation of professional knowledge, skills, personal qualities, adequate qualification requirements and ethical standard of the profession.

The task of a social specialist is to help the client find themselves, find their place in a dynamically changing world, navigate new social relationships, and communication is a very important tool in this process.

A social specialist should have the skills of self-regulation, self-organization (to be able to absorb their thoughts, feelings, behavior, self-observation), which is the basis of self-improvement and professional growth. 
In special, severe or extreme conditions, when external or internal factors disturb the normal activity of functional systems, emerges natural need to restore balance of mental processes. The system of mental self-regulation and the need to «gather», «mobilize», or «rebuild» is activated as a result of the awareness of the situation, when a motive for a specific action appears in order to adapt to a non-standard environment. This is characteristic of the beginning of reflection, when the mechanism of introspection and self-assessment, and decision-making is most often launched.

The social specialist should know: Ukrainian legislation, legislative acts, methodological and other regulatory documents and materials that regulate the organization of social work; organization of social and medical work; organization of legal aid, care, guardianship, care, social rehabilitation, social protection; sociology; psychology; technologies of social work; national features of life, culture of human relations and more. Qualification requirements for a social work specialist are higher education (Master or Specialist's degree) and advanced training.

That is why the main task nowadays is the professional formation of the personality of the social specialist as a subject of social relations, capable of making changes in society, realizing professional functions qualitatively and creatively, and mastering the means of self-organization and self-regulation, self-formation and self-realizaion.

\section{Current professional activity of specialists in the social sphere}

Social work was initiated in connection with the development, formation, regulation mechanisms and interaction of interpersonal relations in order to improve the level of functioning of society and solve problems that arise in the process of social existence. Undeniable is the fact that social work has emerged as a historically conditioned phenomenon, the prerequisite of which was the unselfish help, care and display of charity.

The professional activity of a specialist in the social sphere should be oriented to work with all categories of the population, be directed to the activation of socio-cultural and socio-pedagogical functions of society, family, community, and individual. Specialist in the social sphere is called to create a system of social assistance to the development of personality, create the conditions for the greatest promotion of psychological comfort. 
The Ministry of Social Policy of Ukraine is actively engaged in introducing innovations into the social sphere. In the areas of innovation in the social sphere, as described above, thorough methodological work was carried out, pilot projects were carried out and implemented (for example, on the issues of reforming the social assistance system, introduction of the single window system, development of information and analytical systems for accounting and monitoring of social benefits, paradigms of social services system, transition from maintenance of social service institutions to assessment of quality of services and construction of social services market, etc.). Significant scientific and practical contributions to social innovation in Ukraine have been made with the support of international donors such as the World Bank, various European Union projects for Ukraine, both domestic and international. Such projects create a unique forum for Ukrainian and European professionals, involving government, public and potential commercial organizations in the dialogue [1].

The actions of a specialist in the social sphere in his professional roles are a set of specific operations necessary to implement a number of professional functions, in particular: diagnostic (diagnostics, analysis and evaluation of social work objects); prognostic (forecasting and modeling of social work of all social institutions in society); human rights protection (use of legal support to protect the rights and interests of clients); organizational and managerial (organization of activities of social services to provide various types of assistance and social services to the population); socio-economic (promoting and providing the necessary assistance and support to different categories of the population); control and supervision (exercising control over the implementation of the decisions made, targeted use of the funds provided for pinpointed social assistance); communicative (formation of strategy and tactics of cooperation of social sphere specialist with clients and interprofessional interaction); preventive (implementation of social, judicial, legal, medical, psychological, pedagogical and other mechanisms of preventing and overcoming social destruction); psychotherapy (counseling, adjustment and assistance to different categories of population); medical (introduction of healthy lifestyle of the population); pedagogical (identification of interests and needs of people in different activities); educational (formation of interest of social sphere specialists in training and advanced training, use of innovative teaching methods, new technologies); research 
(identification of problems, specific topics of research; selection, analysis of reference maerials, experience; use of scientific methods of gathering primary information and its processing); advertising (organization of advertising of social services, propaganda and dissemination of ideas of social protection of the population).

At the present stage, a large number of public and private educational institutions carry out professional training of social sphere specialists in the higher education system, but it is at the stage of reform and continuous improvement of both theoretical and practical provisions in accordance with the conditions and prospects of the state development.

The need to improve the training of social specialists is conditioned by the current state of urgent problems of social development presented in the «Strategy of innovative development of Ukraine for 2010-2020 in the context of globalization challenges» and the prospects for development in the higher education system and the perfection of the educational and scientific process presented in» Concepts of humanitarian development of Ukraine for the period up to 2020». That is why it is necessary to take into account the modern tendencies of the development of higher education for training of specialists in the social sphere, whose bases are the processes of globalization, integration and systematization introduced into a single educational and scientific space, the development of technologies and innovations in the higher education system in the direction of social work that defines the professional levels, skills, and competences.

According to the above-mentioned provisions, we have determined the leading criteria and indicators for the training of specialists in the social sphere, which will affect the effectiveness of their future professional activity, in particular: identification of the main labor market requirements for the development of a regional component; organization of the learning process (modeling, forecasting, development strategy and application of technologies for educational innovative environment, methodical and administrative support of the educational process based on the latest achievements of psychological and pedagogical science); application of psychological and pedagogical support of the educational process (content, forms, methods, and techniques); innovative content of educational and professional programs, qualification characteristics of specialist training; increased efficiency of students' independent research work in the relevant training area; compli- 
ance of scientific and pedagogical workers with the modern requirements of higher education (advanced training, inernships, mutual visits and analysis of training, work experience exchange, etc.); integration and partnership (involving state and non-governmental institutions, institutions and organizations for interprofessional interaction).

Implementation of the leading criteria and indicators is characterized by a number of contradictions that characterize the interaction of various aspects of training social specialists, which have inconsistency or inconsistency under the influence of social problems, socially dangerous phenomena, requirements of social work and society's requirements to a specialist in the social sphere.

The effectiveness of such implementation within the interaction of trends implies awareness of the methodology of social work in the complex study and systematic consideration of any process or phenomenon, the definition of principles that ensure its effectiveness, in particular: taking into account the requirements of the labor market with respect to the relevant specialists; coherence of the content of the step by step training of specialists in the social sphere; content and systemic nature of the educational process in higher education institutions; flexibility and variability of educational and professional programs; individualization and specialization due to the necessary balance between the number of normative disciplines (general and vocational training) and elective educational disciplines (general and vocational training based on the free choice of student and higher education institution); consistency and continuity in teaching educaional material; dynamic, gradual complication of tasks suited to different types of educational and practical activity, implementation of an interdisciplinary approach; feedback of theoretical learning and practice; expansion of the range of social roles and activities; performance of various professional functions by students during training sessions and practice.

One of the main aspects of the professional activity of social specialists is educational work, which includes: interactive lectures on social work issues (the main form of training, which is not purely informational in nature, but mostly problem-setting and searchable); workshops (an active form of learning, similar to trainings and business games, which gives the opportunity to activate the full potential of the individual, awaken his/her curiosity, activate emotions, etc.); specialized trainings (an interactive form of 
teaching whose purpose is the transfer of knowledge by way of theoretical lectures, business games with further analysis, as well as practical classes, the result of which is the formation and development of certain social interaction skills); master classes (method of teaching and specific training to improve practical skills most often taught through direct and commented demonstration of working methods); discussion methods (methods that create the conditions for expressing one's own views and beliefs, comparing them with the opponents' positions, defending one's opinion); social design (scientific and practical activity aimed at diagnostics of actual and perspective social problems, development of resource-provided optimal options for their solution) [12].

Thus, the professional activity of a specialist in the social sphere is a multidimensional concept aimed at addressing issues regarding the functioning of the social system, improving the conditions and quality of a person's life, improving his/her social well-being and quality of life

\section{Organizational and methodological support of the process of training social specialists}

Today, research papers, monographs, dissertations and other scientific works on a certain issue largely cover the psychological, social and social-pedagogical support of people of different categories who need help (V. Antonova, S. Arkhipova, L. Volynets, L. Gritsenyuk, I. Ivanov, I. Kozubovskaya, G. Laktionova, I. Pesha, S. Tolstoukhov, etc.); the above works reveal the essence of a specialist's activity in different directions in the social sphere (O. Bezpalko, R. Vainola, V. Gordienko, L. Dimitrova, V. Zhmir, I. Zvereva, A. Kapska, L. Mishchik, O. Pesotska, V. Petrovich, V. Polishchuk, L. Sedina, V. Shapovalov and others); certain scientific basis of social work are revealed in the works of B. Wolfov, L. Dimitrova, I. Zvereva, I. Mygovich, A. Mudryk, O. Petrovsky, B. Shapiro; domestic and foreign practical experience of social work and training of specialists of different levels is covered in the scientific works of I. Andreev, O. Bartosh-Pichkar, R. Weinola, N. Gorishna, O. Ivanova, G. Laktionova, G. Leshchuk, O. Orzhekhovskaya, I. Peshi, O. Prishlyak, V. Tymenko, M. Firsova and others.

Certain aspects of becoming a professional social worker have been revealed in scientific research by V. Bocharova, O. Dubaseniuk, E. Zeer, N. Klimenko, V. Kushnir, A. Lyashenko, V. Plascheva, V. Polishchuk, 
V. Radul, V. Slastionin, N. Shmelova; questions of modernization of the educational process in higher education (V. Kremen, K. Korsak, V. Kushniruk, V. Lozova, P. Oliynyk, O. Popova, I. Prokopenko, O. Suhomlinskaya, etc.); questions of professional training of social specialists (C. Arkhipova, V. Bocharova, N. Zobenko, A. Kapska, A. Lyashenko, I. Melnichuk, V. Polishchuk, L. Tupti.)

The professional responsibilities of a social specialist determine his/ her role. They act as social educators, teachers, tutors, experts, consultants, when they give advice, teach various skills, effective methods of family planning and management, establish feedback, use role-playing games and more. The specialist acts as a mediator, organizer, administrator, when his/ her activity is aimed to help overcome person's problems in difficult life situation. He/she acts as a social lawyer when representing the interests of a client or group of clients, such as when establishing or depriving them of parental rights, guardianship, etc.

The specialist fulfils his or her obligations by working in the social services, institutions, companies and organizations of various agencies, in educational, cultural and medical institutions, homes, neighborhoods or social service institutions for families, as well as in private practice. The activity of a specialist in his/her professional roles represents a set of specific operations required for the implementation of a number of professional functions.

The content of the social specialist activity distinguishes such functions [3; 8]: institutional (organization of social services, involvement in the work of the public and directing activities to provide various types of assistance and social services); mediating (providing assistance and participation in solving the problem of authorities and other social institutions); human rights (application of laws and their legal acts to protect the client's rights and assist him /her); information (provision of information by social services to those in need of social assistance); psychological, pedagogical, social-medical, social and consumer services (identification of the need for providing appropriate assistance to different categories of population) and others.

The following functions are distinguished by the technologies used: diagnostic (making a social diagnosis, determining the content of a group or individual problem); prognostic (forecasting the development of social processes and developing models of social behavior); preventive (activation 
of mechanisms for preventing negative social phenomena); rehabilitation (organization of work on social adaptation and rehabilitation), etc.

When fulfiling a variety of professional roles and functions, the specialist develops a special style of behavior, a system of his or her own unique activities to provide social assistance and customer support.

Great importance for successful professionalization is the orientation of social specialists, which consists of a system of values and motivation of their activity. It results in professional suitability for practical social work.

Researchers note the importance that in the early stages of social and professional formation, future social specialists begin contemplating their life choices, see its connection with the object and purpose of the chosen profession, they find the necessary conditions for successful acquisition of appropriate skills and competences involved in specially organized activities to develop their socio-professional guidance and experience.

The analysis of reference sources and modern practice made it possible to identify and characterize the following leading principles of organizational and methodological support for the process of training social specialists: basic principles of the cognitive theory: objectivity, scientific grounding, historicism, a comprehensive approach to the study of social reality phenomena; the fundamental nature of the social specialist training lies in its content which provides a learning system-related knowledge, which is at the basis of formation, and in the future - their own professionalism; continuity in the content of education, helps identify effective approaches to the application of innovative methods and technologies for its implementation at all levels of specialization; problems and innovations in the organization and implementation of quality education of future specialists in the social sphere; communication and intercultural interaction, whose application provides effective formation of skills and abilities for the purpose of diverse intercultural communication; ensuring an international standard of training as one of the important indicators of the quality of future professionals in the social field, consistent with the objective international standard methods of assessment.

Therefore, the training opportunities of the future social specialists is the result of the totality of the following competencies acquired in the process of studying in higher education establishments.

- educational and cognitive, which allows to improve the training process, increase its efficiency of assimilation and productivity of appli- 
cation, contain common competencies (knowledge), in particular: general knowledge about social systems and general doctrines; knowledge of different approaches to the interpretation of cultural facts; a sufficient level of knowledge of anthropological, sociological knowledge, psychological, sociological, and historical information related to the concept of interprofessional exchange; knowledge of geopolitical concepts; understanding of the essence of secularism and its consequences; knowledge of philosophical approaches to tolerance, pluralism, social justice, particularism, and universalism; knowledge of legal and administrative mechanisms of regulating social processes; knowledge of political and social aspects, client rights at international, European and national levels; general knowledge of cultural differences in relation to basic values (parenthood, gender relations, parenting, etc.); understanding of different terminological components of the category "interprofessionalism" (integration, identity, diversity, assimilation, acculturation, ethnocentrism, ethnicization, inculturation, tolerance, mediation, multiculturalism, racism, empathy, relativism);

- interpersonal exchange, which includes the possession of active and reflexive listening skills; ability to distance oneself from own stereotypes; possessing a palette of tools for establishing interaction with representatives of other cultures; ability to evaluate the attitude of the client to the problem situation, the social worker proper, readiness to reorganize the situation in order to improve interaction; ability to identify and mobilize client resources; ability to pause in time to analyze the situation; ability to identify the client as a reliable source of information having his/her own vision of the situation;

- communicative, whose formation provides the ability of the individual to vocally perform interpersonal communicaion in the educational space of higher learning and beyond, which contains the ability to identify and schematically reproduce the system of of the client's communicative codes; ability to diagnose difficulties that may arise in the context of intercultural interaction; the ability to understand each other throughout the customer relationship; the ability to inform the client about the forms of social intervention, his/her social rights, taking into account the ability to understand the information given in the context of personal, group or community specific culture; the ability to identify ethnocentric expressive communicative elements that are important or insignificant in different situations; ability to 
integrate the symbolic, ethical, and subjective context of communication with the consideration of all aspects of communication interaction (client, social worker, institution, society); ability to feel the limits of the permissible and forbidden in intercultural interaction;

- intercultural, which in its essence is an indicator of the formation of the ability of the future social sphere specialist to effectively participate in interprofessional communication at different levels of its implementation;

- socio-cultural, which contributes to the formation of systematic and deep knowledge of another culture, the study and awareness of the traditions and realities of the country or people;

- technical (skills) - the ability to facilitate communication between professionals and clients, clients themselves through the cross-cutting competencies of professional activity, rather than specific, appropriate only for a specific target group; ability to analyze difficult situations taking into account the cultural context; possessing tools to solve problems caused by interaction; knowledge of the methods and techniques of social intervention (diagnostics, mediation, personal support, social orientation, agency, etc.); ability to actualize and apply specific professional skills to taking into account the cultural context of the situation; sufficient awareness of possible pitfalls in the context of interprofessional interaction (relativism, ethnicity, domination, etc.).

In order to determine the training effectiveness of future specialists in the social sphere, the structure of the content of the professional education is defined by the higher education establishment, which includes the following components: social - reveals an individual's understanding of the influence of culture on the behavior of its representatives, therefore revealing the social importance of intercultural engagement in the development of a separate community or society in general and creating an intercultural environment for peace and harmony; psychological and pedagogical characterized by the awareness of the social sphere specialists of the differences represented by a particular culture (stereotypes of behavior, actions, mentality), values of another culture, the formation of abilities and skills to effectively adapt to certain cultural conditions and to establish effective intercultural communication; methodological - involves the availability of appropriate forms, methods and a set of pedagogical tools that contribute to the implementation of the content of foreign language professional training 
and the formation of intercultural competence in the process of training future social sphere specialists [10].

\section{An interdisciplinary approach to the preparation process of the social sphere specialists for professional work}

Professional activity requires the transition from extensive knowledge (methodological and theoretical knowledge, knowledge of the learning process rules and formation of personality, methodological approaches, etc.) to a single organic fusion of professional knowledge that is complex and systematic. In order to amass a well-defined amount of professional knowledge, the rules of cognition, perception, and memory certainly require their separation from the amount of other knowledge. Scientific knowledge captures the internal natural abilities of objects that hold generalized means of actions. Practical and constructive-technical activity is based on the scientific (theoretical) knowledge. The theoretical knowledge availability provides prediction of the results and consequences of new practical actions aimed at empirical objects, deliberately seeking ways of influencing that could be realized in the objects of potentiality. The student's acquirement of practical experience requires teacher management, providing the interaction between the teacher and students and students among themselves. The organizational teacher-student interaction principles in the educational process are distinguished in the psychology of higher education esablishmens, in particular, dialogization, problematization, personalization, individualization, and differentiation of the learning process.

According to the principle of dialogization, the lesson (both lecture and practical) should not be transformed into a simple transfer of knowledge. It should be built as a discussion of different points of view, as a common search for truth, that is, in the form of dialogue, not monologue. In such a mode of pedagogical cooperation, creative discussion of various theoretical and practical aspects of the problem, students form and actualize cognitive, professional, and broad social motives.

The principle of problematization involves the systematic creation of problematic situations, conditions for self-identification and setting of students cognitive tasks.

The principle of personalization warns that the personal communication between the teacher and the student is not substituted by a role interaction. It should take place in an environment of equal partnership. 
Principles of individualization and differentiation of learning process provide for taking into account the individual characteristics and interests of students, creating the most favorable conditions for the development of their abilities and biases. As a result, students have increased responsibility, ability to solve tasks, the ability for self-regulation and higher self-esteem.

Characterizing cross-curricular connections, it should be noted that in the "Pedagogical Dictionary» they are interpreted as «a didactic tool, which involves a comprehensive approach to the formation and assimilation of the content of education, which allows the connection between subjects for a profound, comprehensive consideration of the most important concepts, phenomena».

According to S. Goncharenko, interdisciplinary connections reflect a comprehensive approach to education and training, that allows to distinguish both the main elements of the content of education and connection between subjects. At any learning stage, interdisciplinary connections perform educational, developmental and determining functions as they increase the productivity of mental processes. We believe that understanding the nature of the interaction between the elements of individual disciplines - linear (identifying new knowledge to deepen the already acquired one); opposite (new knowledge refines or guides previously learned information); problematic (new knowledge creates the conditions for solving the educational task) will help determine the role of interdisciplinary material at the lesson. Understanding the nature of meaningful connections, which can be synchronous (material of related disciplines is processed simultaneously), reproductive (based on learning from other subjects), promising (a certain issue is viewed only on the basis of the main features focusing on more detailed study in a different subject).

Formation of professional readiness of the social sphere specialists is to be carried out through the established link between such disciplines as «Technology of social work», «Social work with different categories of clients», «Applied methods in social work», «Legal support of the social protection system», «Social design», «Social work in the field of employment», «Social work management», «Methods of social benefits calculation», etc. In order to understand the reason and possible causes of low-income and poverty, one should bear in mind ha possible social risks cause total or partial disability, which leads to unemployment and other types of income losses, it is neces- 
sary to find out the causes and effects of socio-economic processes on the social welfare of the society which, in turn, is impossible without economic knowledge and undersanding of legal acts regulating the provision of social assistance, benefits, subsidies, and financial compensation for those who live in poor life conditions. Therefore, it is necessary to build a process of training future social specialists to provide clients with socio-economic services when integrating knowledge from different disciplines.

In accordance with the above, we have created a structure of interdisciplinary involvement in the process of training social sphere specialists (Figure 1), which enables gradual acquisition of the necessary knowledge in terms of the disciplines that influence the formation of the readiness of future social sphere specialists [9].

Scholars differentiate three levels of the training content integration, represented by the level of interdisciplinary communication (common structural elements of the content of education, which can be transferred in the direction of any discipline, are at its source); the level of didactic synthesis (involves the training forms integration; the level of integrity (meaningful and procedural integration within the framework of the formation of a new integral subject and the solution of all the didactic tasks of integrated courses). Whereas interdisciplinary communication is the starting point of didactic systems, interconnection of disciplines can be called interdisciplinary integration.

When defining the interdisciplinary integration, it can be characterized as the interpenetration of the content of different disciplines and creation of educational capacity using pedagogical methods, tools and organizational forms of learning process. Such integration requires a complex solution of tasks, including the social worker activity in providing clients with socio-economic services.

The level of interdisciplinary integration wholeness, i.e. substantive and procedural integration within the framework of the creation of a new integral subject and the solution of all the didactic tasks of integrated courses can be implemented in the training courses of «Social Insurance», «Institutional support of social sphere», «Financial support of social assistance», «Legal support of social protection system», and «Types, methods and reporting of social services». The ultimatelevel of interdisciplinary integration is the level of didactic synthesis, which involves the integration of training forms. 


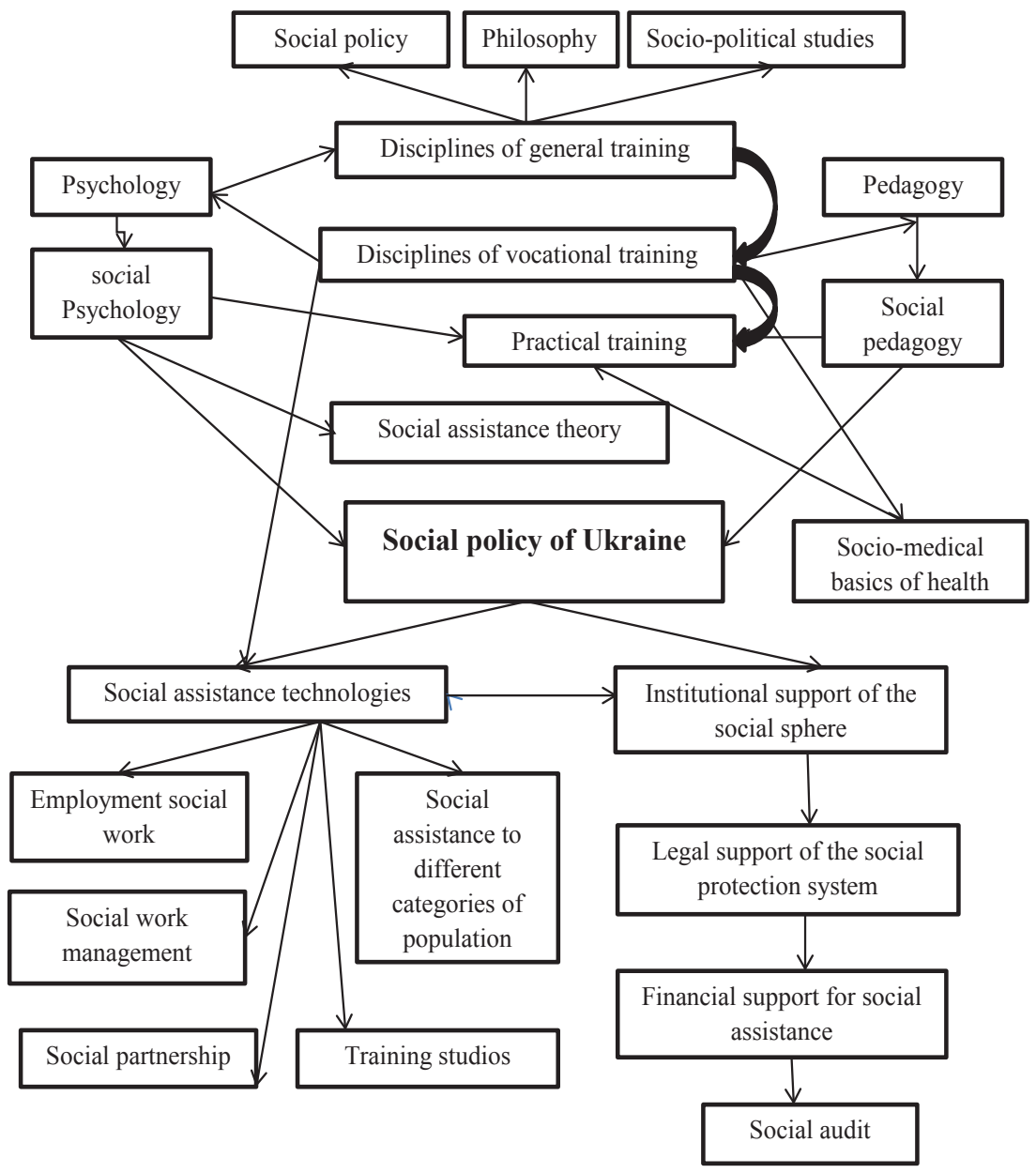

\section{Figure 1. Structure of interdisciplinary integration in the process of training specialists in the social sphere}

Source: created by author Y.M. Rayevska

Here one can use both traditional forms: lectures, practical classes, training sessions, and laboratory classes, where future social sphere specialists are offered problematic, searchable tasks. 
In practice, the interdisciplinary approach can be implemented in two main areas. In the first, more widespread, interdisciplinarity establishes the connection between different sciences (disciplines), integrates them informally without violating their independence, uniqueness, originality. In the second approach, interdisciplinarity emerges as a real instrument for sciences (disciplines) integration, emergence of integrated products, projects, interdisciplinary objects of research, and their further acquisition is of a great importance for both science and education.

In modern teaching practice with relation to social specialists professional training disciplines use the interdisciplinary approach which is effective in terms of theoretical knowledge and practical skills acquisition. The following methods, forms and techniques can be defined as brainstorming; «decision tree»; discussion with the involvement of experts; business games; commentary, evaluation (or self-evaluation) of participants' actions; master classes; method of analysis and diagnosis of the situation; PRES formula (from English Position - Reason - Explanation or Example - Summary) project and modeling method - a method aimed at developing and consolidating the skills of argumentation, justification and defense of one's position in discussion, dialogue; during business meetings; problem-setting method; public address; work in small groups; and inter-curricular trainings.

However, we emphasize that establishing interdisciplinary connections does not mean a rejection of the disciplinary approach to knowledge acquisition.

\section{Practical vocational training of social sphere specialists}

Not only theoretical but also practical training is essential for the preparation of a social work specialist. Moreover, the correlation between theory and practice should be almost equal. Therefore, in the context of active professionalization of social work, changes in educational standards and introduction of new educational programs, including Specialties 231 Social Work and 232 Social Welfare, it is important to focus on the practical training quality of future specialists in the social sphere.

The professionalism of a social work specialist consists in professional knowledge, skills and competences. Mastery of skills and competences is an integral part of the specialist's practical training, which is usually formed during workshops and continuous practice. 
We consider the practical training system as a structural component of an integrated university vocational training system. After all, practical training includes not only the traditional elements adopted in many educational institutions, such as introductory, educational and occupational, practice within the specialization, but also significant changes and additions to theoretical courses: fulfillment of laboratory tasks, practical assignments and term papers related to the aspects of practice conceptually, substantively and organizationally; specifically arranged training sessions and workshops; exchange of experience, research-practical and methodical conferences; volunteer activity in occupational associations and public organizations.

Practice involves constant creative search, self-development and formation of professional skills, personal and professionally significant qualities of a future specialist, as well as establishing conditions for introspection and self-improvement of professional activity.

The professionalism of the future social sphere specialist consists in professional knowledge, skills and competences. Mastery of skills and competences is an integral part of the specialist's practical training. The organization of practical training of students is prescribed by the Regulations on Conducting the Practice of Higher Education Students, the Regulations on the Educational Process Organization at Ivan Ohiienko National University Kamianets-Podilskyi, August 30, 2018 (Report No. 7) [7].

Training and professional practices are part of the educational process, a crucial phase and an important link in the training system of future specialists in the social sphere. It is in internship that the student can understand whether he/she has chosen the field of activity correctly and test the acquired theoretical knowledge.

The training ground for students are general education establishments as well as inclusive education establishments, state organizations of the local social welfare system, and social services providing social care.

During the internship, students communicate with representatives of different ages, children (adults) of different social experience, which requires practicing students to study individuals systematically and purposefully, identify their interests, features of physical development, and character. It requires appropriate theoretical training.

Moreover, students are constantly learning to establish psychological contacts with strangers, manage children at different levels of development and 
study the environment and conditions of the respective institution or establishment. They acquire professional skills on the basis of practical work.

During practice, the process of forming professional skills and competences is particularly intensive, since it is carried out in conditions as close as possible to future professional career, and it actually provides the organization of independent practical activity aimed at solving specific professional problems.

It should not be ignored that little time is devoted to practice. The role and place of practice in a holistic system of social work professionals training is evidenced by the fact that, for example, in the Social Administration Department at the University of Edinburgh (UK), the teaching process is carried out by 7 full-time teachers, 3 part-time teachers and 37 instructors who are responsible for carrying out the practice [5].

During and after undergoing volunteer integral training at the Kamianets-Podilskyi Social Services City Center for Family, Children, and Youth, students are involved in volunteer activities. They participate in the preparation of street toy libraries, preventive work with children, youth and families, training sessions, vocational exhibitions, and workshops. They conduct charitable activities together with the Center staff to support families with children in need of targeted assistance, various city-wide social events.

Volunteer students have special motives for self-imposed social work; they receive awards for their charitable, selfless activities.

Primarily, their professional interests are concerned with obtaining a specific social work experience, developing communication skills with clients. That is why the students who chose Social Work and Social Assistance specialties are motivated by professional preference, rather than formally try to use volunteer work to gain experience in their future professional activities, new social work technologies, to find a future job or to get rid of certain personal problems, such as being able to communicate with customers, find new friends, assert oneself, etc. Experience with volunteer students indicates that they are most attracted to the types of volunteer work which are directly related to their future professional activities.

Training of students for professional practice includes the following main areas: professional training, which is implemented through theoretical and practical educational disciplines, professional education of students, their involvement in the professional activity of a social sphere specialist 
and the formation of professional orientation and other vocationally important qualities.

Professional practice should be considered not only as an important means of training professionals, as a component of their professional training and as an organizational form, but also as a factor of self-development, formation of individual creativity potential in the implementation of future activity, improvement of the professional skills level of future social studies teachers. Professional practice is both the content of future activity and the professional skills improvement program for students.

Many practicing students are interested in professional issues. It is important for them to communicate with professionals in their chosen field, become familiar with new methods and technologies, everything that can help them become highly qualified specialists and get a job in the future. Quite often, students prefer to work individually or in small groups. Individual work is when a student is entrusted, for example, with counseling, and work in small groups for research or group counseling, etc. It is important to see the best in each student, something that can be relied on.

Most of the tasks of professional practice help practicing students to test professional knowledge, form students' creative research approaches to future activity, learn modern work technologies with different categories of clients.

Therefore, practice is one of the most important components of the professional and practical training of the future social sphere specialist. It allows the student to gain experience of future professional activity, to practically try his/her hand at the chosen career, and learn to apply the obtained theoretical knowledge.

\section{Conclusions}

Professional training is a productive process of development and self-development, acquisition and self-design of professionally oriented activities, identification of one's place in the professional world, realization of oneself in the career and self-actualization of one's potential to become a real professional.

Professional development effectiveness of a social work specialist depends on the following conditions: psychological compliance with the requirements of the profession; focus on social sphere activities (a strong interest and aptitude for the occupation); and content and technology of the vocational-educational process in the educational establishment and others. 
Training of a social work specialist becomes the key to successful professional career, helps adapt to social environment changes, focuses on social affairs, determines personal, social and professional perspectives, also develops altruism, responsibility, culture, and empathy; promotes self-realization in professional field, social-psychological potential realization of the individual, which is caused by the social work functions in general and their specificity in accordance with the directions of activity in the social sphere (population categories, areas of life, social issues, etc.).

The issues of professional training of social specialists should be solved in close connection with the modern achievements of the professional education theory and methodology.

The interdisciplinary approach will provide an opportunity to study the research object using the scientific accumulation of already acquired knowledge. The study of individual disciplines should be accompanied by the establishment of techniques and approaches to the interdisciplinary educational material presentation, which forms interdisciplinary thinking, that will contribute to the successful professional development of social field specialists.

As an important link, practice in the system of training future social sphere specialists, contributes to professional competence improvement of students, the development of value and content sphere of future specialists, self-disclosure and self-knowledge, optimization of the student development process for actual professional career. We consider that it is advisable to introduce continuous practical training in the professional training process of future social sphere specialists, starting from the first year to graduation; improve the quality of education and methodology of higher education applicants' practices, taking into account the array of general and professional competences presented in educational programs of the respective specialty; and define criteria for evaluating the results of practical training in the work programs.

\section{References:}

1. Bezpalko O.V., Zvierieva I.D. (2008). Intehrovani sotsialni sluzhby: teoriia, praktyka, innovatsii [Integrated Social Services: Theory, Practice, Innovation]. Kyiv: Phoenix. (in Ukrainian)

2. Bukach M.M., Klymeniuk, N.V., Horlachuk V.V. (2015). Slovnyk-dovidnyk iz sotsialnoi roboty [Dictionary-directory of social work]. Mykolaiv: FOP Shvets V.D. (in Ukrainian) 
3. Kapska A.I. (2010). Deiaki aspekty profesiinoi pidhotovky sotsialnykh pedahohiv i fakhivtsiv sotsialnoi sfery [Some aspects of the vocational training of social educators and specialists in the social sphere]. Visnyk Hlukhivskoho natsionalnoho pedahohichnoho universytetu im. O. Dovzhenka. - Glushkiv National Pedagogical University. O. Dovzhenko: Seriia: Pedahohichni nauky, vol. 15. (in Ukrainian)

4. Karpenko O.H. (2014). Teoriia i praktyka profesiinoho stanovlennia sotsialnoho pratsivnyka : navch. posib. [Theory and Practice of Social Work Professional Development]. Kyiv: Publishing House «Word». (in Ukrainian)

5. Lohvynenko T.O. (2010). Osoblyvosti profesiinoi pidhotovky sotsialnykh pratsivnykiv u systemi vyshchoi osvity Danii [Features of Vocational Training of Social Workers in the Higher Education System of Denmark]. Social Pedagogy: Theory and Practice, vol. 1. (in Ukrainian)

6. Melnychuk I.M. (2011). Teoriia ta metody navchannia maibutnikh sotsialnykh pratsivnykiv zasobamy interaktyvnykh tekhnolohii vyshchoi osvity [Theory and Methods of Training Future Social Workers by Means of Interactive Technologies in Higher Education]. Ternopil. (in Ukrainian)

7. Melnyk L.P., Raievska Ya.M., Melnyk Zh.V. (2019). Mizhprofesiina vzaiemodiia yak umova uspishnoi diialnosti fakhivtsiv sotsialnoi sfery: tezy dopovidei Vseukrainskoho naukovo-praktychnoho seminaru [Interprofessional Interaction as a Condition for Successful Activity of Social Workers]. Abstracts of the AllUkrainian Scientific and Practical Seminar. Kamianets-Podilskyi: Medobory 2006. (in Ukrainian)

8. Oresheta Yu.V. (2014). Fakhivtsi iz sotsialnoi roboty yak kliuchovi subiekty sfery sotsialnoi roboty [Social work professionals as key actors in the field of social work]. Hrani, vol. 11, pp. 124-129. Retrieved from: http://nbuv.gov.ua/UJRN/ Grani_2014_11_25

9. Raievska Ya.M. (2019). Osoblyvosti zdiisnennia mizhdystsyplinarnoho pidkhodu v protsesi pidhotovky fakhivtsiv sotsialnoi sfery do mizhprofesiinoi vzaiemodii [Features of Implementing an Interdisciplinary Approach in the Process of Training Specialists in the Social Sphere in Interprofessional Interaction]. Collection of research papers of Kamianets-Podilskyi National University named after Ivan Ogienko. No. XXIII. Series: Socio-Pedagogical. L.P. Melnyk, V.I. Singer (Ed.). Kamianets-Podilskyi: Medobory, 2006. (in Ukrainian)

10. Raievska Ya.M. (2019). Psykholohichne zabezpechennia profesiinoho stanovlennia fakhivtsiv sotsialnoi sfery do mizhprofesiinoi vzaiemodii: orhanizatsiino-metodolohichnyi aspekt [Psychological Support of Professional Training of Social Sphere Specialists in Interprofessional Interaction: Organizational-Methodological Aspect]. Theory and Practice of Modern Psychology, vol. 6. (in Ukrainian)

11. Kholostova E.Y. (2006). Sotsyalnaia rabota [Social work]. Moskva: Yzdatelsko-torhovaia korporatsyia «Dashkov y K». (in Russian)

12. Yana Raievska (2020). Analysis of psychological readiness for interprofessional interaction of social workers: theoretical and methodological aspect. Professional competencies and educational innovations in the knowledge economy: collective monograph / Editors Lyubomira Popova, Mariana Petrova. Veliko Tarnovo, Bulgaria: Publishing House ACCESS PRESS, pp. 458-473. 